\title{
Socio-economic profile of arid and semi-arid agropastoral region of Borana rangeland Southern, Ethiopia
}

\begin{abstract}
Ethiopia is believed to have the largest livestock population in Africa. This livestock sector has been contributing considerable portion to the economy of the country and Borana zone is the major contributor for this. The main objectives of the study were to make basic information regarding natural features and socio-economic conditions of the zone that serve or stepping ground for planning policy making and research. This data is crucial for designing proper development plan for research activities and decision making. Specifically, the 2019 socio -economic profile was conducted to provide basic information for the 2020 national election purpose and for 2021 population and housing census as preliminary document regarding socio-economic condition of the zone. And also, this socio-economic profile is used to enhance tourism and economic development, identifying under used services (or opportunities for shared services, forecasting problem areas, developing local community profiles and better land use planning. In organizing this document, the serious problems were the absence of reliable data and up to date data and information. The document being the first of its kind gives a general clue about the zone and accordingly could be used as a bench mark for further study about the zone.
\end{abstract}

Keywords: Borana, socio-economic, livestock, pastoralists
Volume 5 Issue 3 - 2020

\author{
Yeneayehu Fenetahun, ${ }^{1,2}$ Tihunie Fentahun ${ }^{3}$ \\ 'Biodiversity center, Ethiopian biodiversity institute, Ethiopia \\ 'University of Chinese Academy of science (UCAS), Xinjiang \\ Institute of Ecology and geography, China \\ ${ }^{3}$ Collage of Natural and Computational Science (CNCS), \\ Mekdela Amba University, Ethiopia
}

Correspondence: Yeneayehu Fenetahun, University of Chinese Academy of science (UCAS), Xinjiang Institute of Ecology and geography, 8300I, Urumqi, China, Email yeneayehu7@gmail.com

Received: April 24, 2020 | Published: June 03, 2020

\section{Introduction}

\section{Background of the zone}

Borana zone is among the 20 zones found in Oromia regional state. The establishment of the zone was twice in the history. Firstly, the zone was separated from the former Borana zone (which includes the present Guji Zone and West Guji Zone) and re-established at the end of 2002 by including the present west Guji zone jointly known as Borana zone. ${ }^{1}$ Second time, at the end of 2016 the zone established again separated from the highland woreda's of west Guji zone and left with almost all lowland pastoralist areas. Currently, the zone has thirteen rural pastoralist woreda namely, Arero, Dhas, Dillo, Dirre, Dubluk, Eelwoye, Gomole, Guchi, Miyo, Moyale, Taltale, Yaballo and Wachile and one town administration Yabello town which has the state function. ${ }^{2}$ There are 134 rural kebeles (PA) and 11 town kebeles in the zone; most of the districts haven't basic services like telephone, water, banking and others. According to the 2019 Central Statistics Agency projection there are 503,877 people living in the zone whereas, male to female ratio is $1: 1$ and about 23 people are living in $1 \mathrm{~km}^{2}$; entirely sparsely populated. ${ }^{3}$ This indicates that there is great difference in settlement between districts to districts. About $89 \%$ of the populations are living in the rural pastoralist areas of the zone. The zone is found in the southern part of the Oromia region. It shares borderline with west Guji zone to the north, Southern nation, nationalities and people to the west, Somali region to the southeast and to the south an international boundary with Kenya. The most ethnic group of the zone are inhabited by Oromo people of Borana, Guji and Gabra; the other Gari, Somali and various tribe of nation, nationalities and peoples are also living in the zone. Concerning the livelihood activities, the district and smalltown dwellers are engaged in small trade while the others employed in different government and non-government organization offices. ${ }^{4}$ The life of rural community is mainly depending on pastoral and small rain fed agro-pastoral activity. Erratic rainfall is common in the area that accompanied with drought and desertification which results the death of numerous cattle in almost every year. ${ }^{5}$ The capital of the zone is Yabello town which is located $570 \mathrm{~km}$ from the capital city of the country Addis Ababa. The town is on rapid growth and suitable for different investment activities.

\section{Methods and materials}

\section{Study area location and general information}

Astronomically, Borana zone is located $4^{\circ} 3^{\prime}$ to $5^{\circ} \mathrm{N}$ latitude and $37^{\circ} 4^{\prime} \mathrm{E}$ to $38^{\circ} 2^{\prime} \mathrm{E}$ longitudes and the landscape is characterized by slightly undulating peaks up to 2000 meters above sea level (masl) in some areas. ${ }^{6}$ It is located in the southern part of Oromia regional state. Borana zone shares common boundaries with Guji zone in the east, Somali regional state in south east, southern nation's nationalities and peoples of southern Ethiopia in the west and one international boundary with Kenya government $521 \mathrm{kms}$ (Figure 1).

\section{Geology of the zone}

Borana zone has its oldest rocks of pre-Cambrian origin syntectonic gramitods upper and lower middle protozid (metamorphic) and lower complex (archalan metamorphic) of precam brian an or basement complex rocks origin have been found in several parts of the zone particularly in the Yabello and Mega. ${ }^{1}$ Similarly, Mesozoic and Cenozoic deposition have been exposed in Yabello, Dire, Arero and Teltele. 


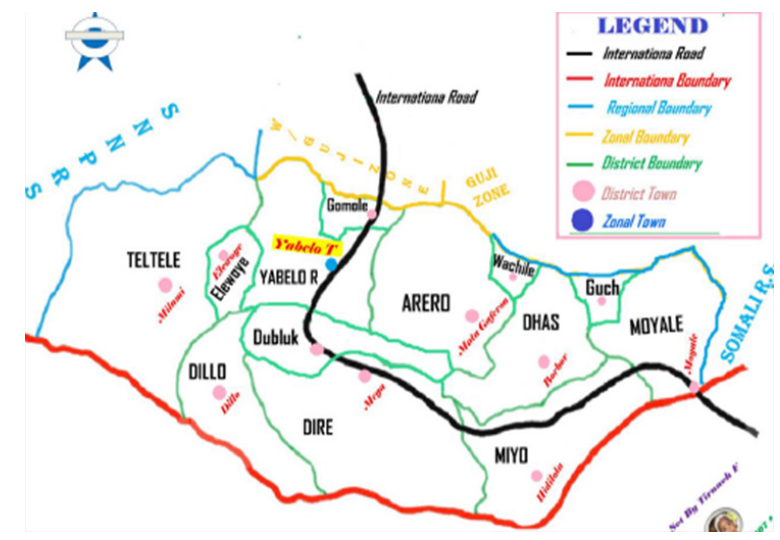

Figure I Map of Borana zone.

\section{Relief, drainage and climate}

Relief: Borana zone is not a region of great physiographic diversity. It has no very low and very high areas however; very large areas of the zone are altitude below 1500 above sea levels found in the low land areas can be categorized as "Gamojji" with semi-arid climate.? These wide areas are found in the south west and eastern parts of the zone this includes Moyale, Dire, Arero and Yabelo. The high lands (over 1500 above sea level) are found in north central and southern parts these in particularly it includes Yabello and central parts of Dire. Yabello-Mega plateau; the extension of southern highland which rises to $2000 \mathrm{~m}$.

Drainage: There are no rivers and streams that drain widely across Borana zone, only the rivers of Segen which raises somewhere around Burji-Teltele boundary and flow North West wards ending up in Chew Bahir swamp. Apart from this, there are various small traditional ponds/hand dug which are uses as drinkable water reservoir for cattle and community during dry season.

Season: The zone rain pattern is bimodal type, the 'ganna' or rainy season is from February 15 up to May 15 and the 'Hagaya' or short rain season is from September 1 up to the end of the month of November. ${ }^{7}$

Climatic classification: The climatic classification of Borana zone ranges from hot low land (Gamojji) to cool highland (Badda) and also from semi-arid to humid. This classification is based on annual and monthly mean of temperature and rainfall, seasonal changes of rainfall and type of native vegetation associated with them. There are four climatic type represented in Borana zone. ${ }^{4}$

Hot-arid climate: It is characterized by poor sparse vegetation with mean annual temperature ranging from $27^{\circ} \mathrm{C}$ to $29^{\circ} \mathrm{C}$ and mean annual rainfall less than $450 \mathrm{~mm}$. Evaporation is 20 or more times in excess of precipitation in same area. It is characterized by strong wind, high temperature, low rainfall and low relative humidity with little cloud cover. This area is barren with little vegetation cover and it includes areas of eastern Moyale district.

Hot semi-arid climate: It forms an intermediate climatic region between Arid and humid climatic region. It prevails over areas of steppe type of vegetation cover. Grasses are short and coarse but edible, during the dry season it is highly palatable. Because of this wild animals and cattle's during dry season rely largely on the tender fresh grasses found along the water course. This climatic region has mean annual temperature that varies between $18^{\circ} \mathrm{C}$ to $27^{\circ} \mathrm{C}$ with annual mean rainfall of $410-820 \mathrm{~mm}$ with noticeable variability from year to year. Since evaporation exceeds precipitation, there are no permanent streams. Areas with such kind of climate include western and southern Borana, part of Taltale, Yabello, Moyale, Arero and Dirre district.

Tropical rainy climate: It is a region with distinct dry winter season. The mean temperatures of the cold month are about $180^{\circ} \mathrm{C}$ and mean annual rainfall is generally between $680-2000 \mathrm{~mm}$. Such climate prevails up to an elevation of $1750 \mathrm{~m}$ amsl. This climate is characterized by tall grasses, but grasses and trees are intermingled. Areas dominated by this climatic condition are district of Dirre, south western Moyale and limited area of Arero.

Warm temperature climate: Such climate is found in areas extending in elevation from $1750-3200 \mathrm{~m}$ amsl. It is the areas of heavy rainfall, forests predominant, while in areas of moderate rainfall grass coverage dominate the land cover type. This region includes Yabello and Smaller portions of Dirre and Arero district.

Soil types and distribution: Borana Zone is endowed with a vast but fragile soil resource where mixed crop-livestock sedentary agriculture is practiced in mid-highland and where Pastoralism is the way of life in lowland. The sub region has a mosaic of soils due to the weather and leaching pattern of the varied parent materials under complex environments. The Agro-ecology of the area is intimately related with the geology of the area. According to FAO/UNESCO classification, the soil resources of Borena zone are classified into Vertisols, Cambisols, Luvisols, Nitosols, Calcisol, Gypsisol, Paeozems, Ferralsols, Solonetz, and Fluvisoil. They are 10 major soil types in the zone understudy. However, some of these are localized and of too small spatial extents to appear on so small-scale soil map. Depending on the factors for formation of the different types of soils, major soil groups inclusive of various soil units are identifiable.

Minerals resources: Minerals are natural occurring organic and inorganic substances with a definite chemical and physical composition. The occurrences of these minerals are associated with the distribution of various types of rocks. The geological back ground of Borana zone has provided favorable conditions for the occurrence of variety of minerals. Hence according to some geological studies so far made various types of minerals have been found in district of the zone such us Dire, Arero, DilloYabelo, Taltale, Dhas. The minerals deposits of this zone which can be sub divided in to metallic minerals, non-metallic minerals and gemstone includes nickel, cobalt, rare metals (columbines tantalite), kaolin, feldspar and quartz, talc, graphite muscovite, asbestos, lime stone, gypsums, olivine and garnet. This mineral is not much exploited except same studies (Table 1).

\section{Vegetation}

Major types of natural vegetation: High forest, broad leafed forests, wood land, bush and shrub land, grass land and plantations trees are found in the zone. The high forest sub-classification of upland dry evergreen (juniperusprocera) forest which is known as Forest of Borana is found on the southern escarpment and hills of the zone between 1500 and 2000masl Arero, Mega and Yabello forests are included within this category. Based on the data source from Borana zone Agriculture and Rural Development office, the major types of vegetation found in the area are the following.

\section{Woodland and savannah region}

This region extends from lower to higher elevations ranging from 400 to $2000 \mathrm{~m}$ with mean annual rainfall varying from as low as $250 \mathrm{~mm}$ to over $1300 \mathrm{~mm}$. It consists of three types of woodland and savanna. These are mixed deciduous woodland and savanna, juniperus woodland and savanna and various type of acacia woodland and savanna. 
Table I Mineral resource in Borana Zone

\begin{tabular}{|c|c|c|c|c|c|c|c|}
\hline No. & $\begin{array}{l}\text { Name of } \\
\text { Minerals }\end{array}$ & $\begin{array}{l}\text { Location } \\
\text { (District) }\end{array}$ & PA & Specific potential area & $\begin{array}{l}\text { Protentional } \\
\text { reserved }\end{array}$ & $\begin{array}{l}\text { Come racial } \\
\text { use }\end{array}$ & Rem \\
\hline \multirow{4}{*}{ I } & \multirow{4}{*}{ Gemstones } & \multirow{4}{*}{ Dirre } & Sake Qora & Sake Qoro & \multirow{4}{*}{ Unknow } & & \\
\hline & & & Romso & Romso & & & \\
\hline & & & Magado & $\begin{array}{l}\text { Bule Shalawe, Bule Gando } 7 \\
\text { At another olaces }\end{array}$ & & & \\
\hline & & & Dubluk & Dambalabadana & & $\checkmark$ & \\
\hline \multirow{5}{*}{2} & \multirow{5}{*}{ Gemstones } & Areroo & & \multicolumn{2}{|l|}{$\begin{array}{l}\text { Kara loni, okola, Dogogo } \\
\text { Renji \& at another place }\end{array}$} & & \\
\hline & & Dilloo & & \multicolumn{2}{|l|}{ At many places } & & \\
\hline & & Yabello & Chari & \multicolumn{2}{|l|}{ Chari Qarsa } & $\checkmark$ & \\
\hline & & Taltale & & \multicolumn{2}{|l|}{ At many places } & & \\
\hline & & Dhas & Dhas & \multicolumn{2}{|l|}{$\begin{array}{l}\text { Gara Hara \& at another } \\
\text { places }\end{array}$} & & \\
\hline 3 & Oliven (per dot) & Dire & Romso & \multicolumn{2}{|l|}{ Romso } & $\checkmark$ & \\
\hline 4 & Biotite & Arero & Weyba & \multicolumn{2}{|l|}{ Weyba } & $\checkmark$ & \\
\hline 5 & Aquamarine & Dillo & Dillo & \multicolumn{2}{|l|}{ Duwole } & $\checkmark$ & \\
\hline \multirow[t]{2}{*}{6} & \multirow[t]{2}{*}{ Safir } & Yabeloo & Cari & & & $\checkmark$ & \\
\hline & & Malka soda & - & & & $\checkmark$ & \\
\hline \multirow[t]{2}{*}{7} & \multirow[t]{2}{*}{ Tourmaline } & Dhas & - & \multicolumn{2}{|l|}{ Sora Dhera } & $\checkmark$ & \\
\hline & & Dillo & Dillo & \multicolumn{2}{|l|}{ Bore } & $\checkmark$ & \\
\hline \multirow[t]{8}{*}{8} & Rubby & Yabello & Surpha & \multicolumn{2}{|l|}{ BuyaGudo } & $\checkmark$ & \\
\hline & Gold & Arero & Halo Madeda & \multicolumn{2}{|l|}{ Garibi,OkoteDujuma } & $\checkmark$ & \\
\hline & & & & \multicolumn{2}{|l|}{ Bujujii\& at another place } & $\checkmark$ & \\
\hline & & Moyale & Tuka & \multicolumn{2}{|l|}{ At many places } & $\checkmark$ & \\
\hline & & Yabeloo & Arboro & \multicolumn{2}{|l|}{ At many places } & $\checkmark$ & \\
\hline & & & \multicolumn{2}{|l|}{ DhaddachaTilaa } & & $\checkmark$ & \\
\hline & & & \multicolumn{2}{|l|}{ Abunuu } & & $\checkmark$ & \\
\hline & & Taltale & Saaritee & & & & \\
\hline
\end{tabular}

Source: Zone physical geography office

\section{Juniperus woodland and savanna}

This type of forest found at higher altitude which ranges from $1400-2100$ masl and with mean annual rainfall of 550 to $875 \mathrm{~mm}$. It is confined to Yabello, and Arero district of the zone.

\section{Acacia woodland and savanna}

This region occupies varied environments. It is found at elevation of ranging from as low as 250 to as high as 2200 masl and mean annual precipitation of 300 to $875 \mathrm{~mm}$. Acacia woodland and savanna region is found in the larger areas of the zone including in districts of Moyale, Taltal, Arero, Dire, Dillo, Dhas, Miyo and Yabello.

\section{The grassland region}

This climatic climax region considered as the grassland climatic climax where the dominant vegetation of various species of grass is found within the woodlands and savanna lands at lower elevations with generally drier conditions. It occupies extensive areas of the zone including Moyale, Taltal, Arero, Dire, Dillo, Dhas, Miyo and Yabello.

\section{The steppe region}

This region occupaies altitude of up to $1400 \mathrm{~m}$ with mean annual rainfall of up to $500 \mathrm{~mm}$. It is characterized by scatterd thorny deciduous shrubs and short acacia, with small leaves, less than $4 \mathrm{~m}$ high and usually resine or gum bearing and aromatic. It includes areas of Dhas, Yabello, Arero, Moyale and Dire district.

\section{Natural and man-made forests}

Large Portion of Borana zone is believed as have been covered by forest in the past. These days due to increasing human interference, their coverage is decreasing from time to time. Despite this interference same Pocket areas of forest cover are still found in different parts of the low lands. There are protected government forests partly planted 
by man and partly natural. These forest areas include frost in Arero and forest in Yabello.

It is worth mentioning that these forests are constantly under destruction illegally. The illegal deforestation activities include forest clearing for expansion of farm land, local lumber production, fire wood and charcoal production.

Wildlife: Wildlife is one of the most important natural resources which Borana zone is endowed with. The diverse climate and topography of the zone has provided arrange of natural environments supporting a wide variety of fauna and flora. About 30 species of mammals and more than 300 species of bird life has been recorded in the park. BNP is an interesting ornithological region being a home to $64 \%$ of the Somali-masai bird biome assemblage and habitat to critically endangered birds and mammal species. Bird species habitat in BNP are Ethiopian Bush Crow, White-tailed Swallow, Ostrich, Archer's grey-wing, little spotted wood pecker, Grey-headed Silverbill and little tawny Pipit,Somali Sparrow, Star-spotted nightjar and so on. Some of a remarkable mammal species found in the park includes: - Gravy's Zebra, Grant's gazelle, Gerenuk, bias Oryx, Greater kudu, lesser kudu, Cheetah, Leopard, Lion and so on (Figure 2).

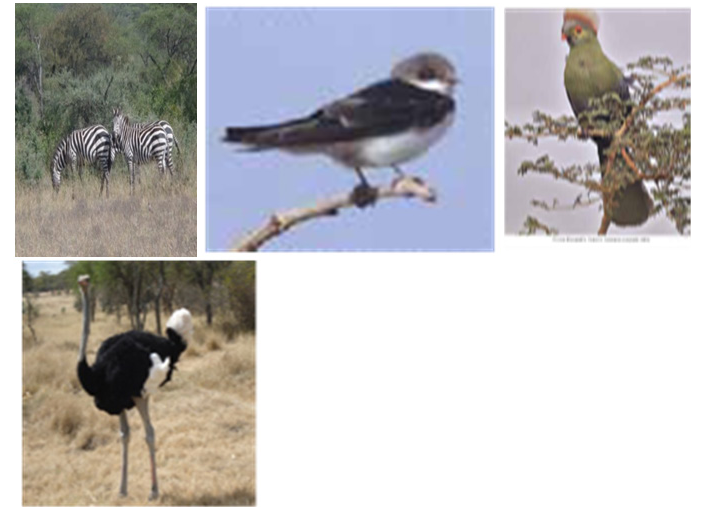

Figure $\mathbf{2}$ Some of the major wildlife species in Borana rangeland zone (Source: Yabello Wildlife Sanctuary and OFWE Brochure, 2019).

However, as the case in other parts of the region the numbers of wild creatures has been decreasing mainly due to the destruction of natural vegetation which is their natural habitat and uncontrolled hunting.

\section{Attraction areas}

Historical and cultural heritages site: An existence of historical and cultural heritage in Borana rangeland site known as Arda Jilaa place where a ceremony/festival for adoring their God has been practiced. This interesting unique experience are connected with Gada Oromo administration system and Borana is where this ceremony is taking place, inscribed manuscript on the top of Walmel mountain and indigenous culture maintained till today.

\section{Boke soda /El-soda/}

Boke soda in Afan Oromo dialect means a natural salt water pond. The natural salt water pond is a creator lake where thousands of Borana and neiboring pastoralist communities get salt for cattle's fattening and consumption. From the top to creator lake is about $3 \mathrm{~km}$ and it is where everybody experiences true adventure while ascending and descending steep slop and in very hot temperature for about 2 to 3hrs (Figure 3).

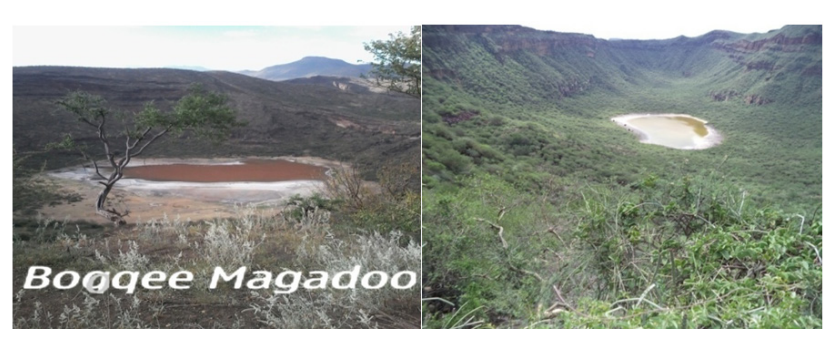

Figure 3 Recreational areas found in Borana rangeland site.

\section{Techniques used to collect source of information}

For this data I used both primary and secondary sources. Primary source of data for this profile was obtained from the field, interviews, focal group discussion, and whereas secondary data was obtained from written documents from government and non-government offices.

\section{Socio economic profile}

Population: According to 2015 population and housing census result projected total population of Borana zone is 503,877 of which 447,913 rural population (225,541Male and 222,372 female) it comprises $88.90 \%$ of total population while urban population was 55,964 (29,342 male and 26,623 female) comprises $11.10 \%$ of total for detail, see the Table 2 below.

\section{Agricultures}

Pastoralist associations: The number of peasant association in 2019, there were 138-peasant association and 14 urban centers in the zone. As to development agents, in 2019 about 428 development agents were available in the zone (Table 3).

Service co-operatives: In Borana zone, cooperative is very important in changing the livelihood life of pastoralist community. Accordingly, in the zone there were 936 cooperative associations and 4unions in 2019.In the same year the number of members of cooperative association were 76,008 their capital was $122,910,958.00$ for cooperative association and $6,961,564.00$ for unions. Saving and credit of cooperative association was 55,940,759.00 in 2019.

Food aids and situation of drought: Borana zone is one of pastoralist zone of which community depends on rearing of livestock and agriculture. There is rain fed agriculture practice in the zone little irrigation practice is found in few were da's of the zone. In the zone the rainfall condition was not sufficient for livestock rearing and agriculture. So, most of the time the communities are vulnerable to drought at different time, this indicates that the community depends on food aid. Different type's grain was distributed at different time to the communities. The data obtained from Borana zone disaster prevention office report indicates, the relief was distributed in different round for people affected by drought the types of grain distributed were edible oil, pulses and CSB (Table 4).

\section{Land use and land cover (Figure 4)}

Crop production: In addition to the rearing of animals, the Pastoralist community of Borana zone is also involved in small amount of crop production. In relation to this, in 2019 during "Belg" season 193,118.2 hectare of the land was cultivated and the production obtained was $2,179,521$ quintals. In addition, in the same year during 'summer' season $144,083.5$ was cultivated and the production obtained was 818,355 quintals (Table 5). 
Table 2 Total population of the Borana zone

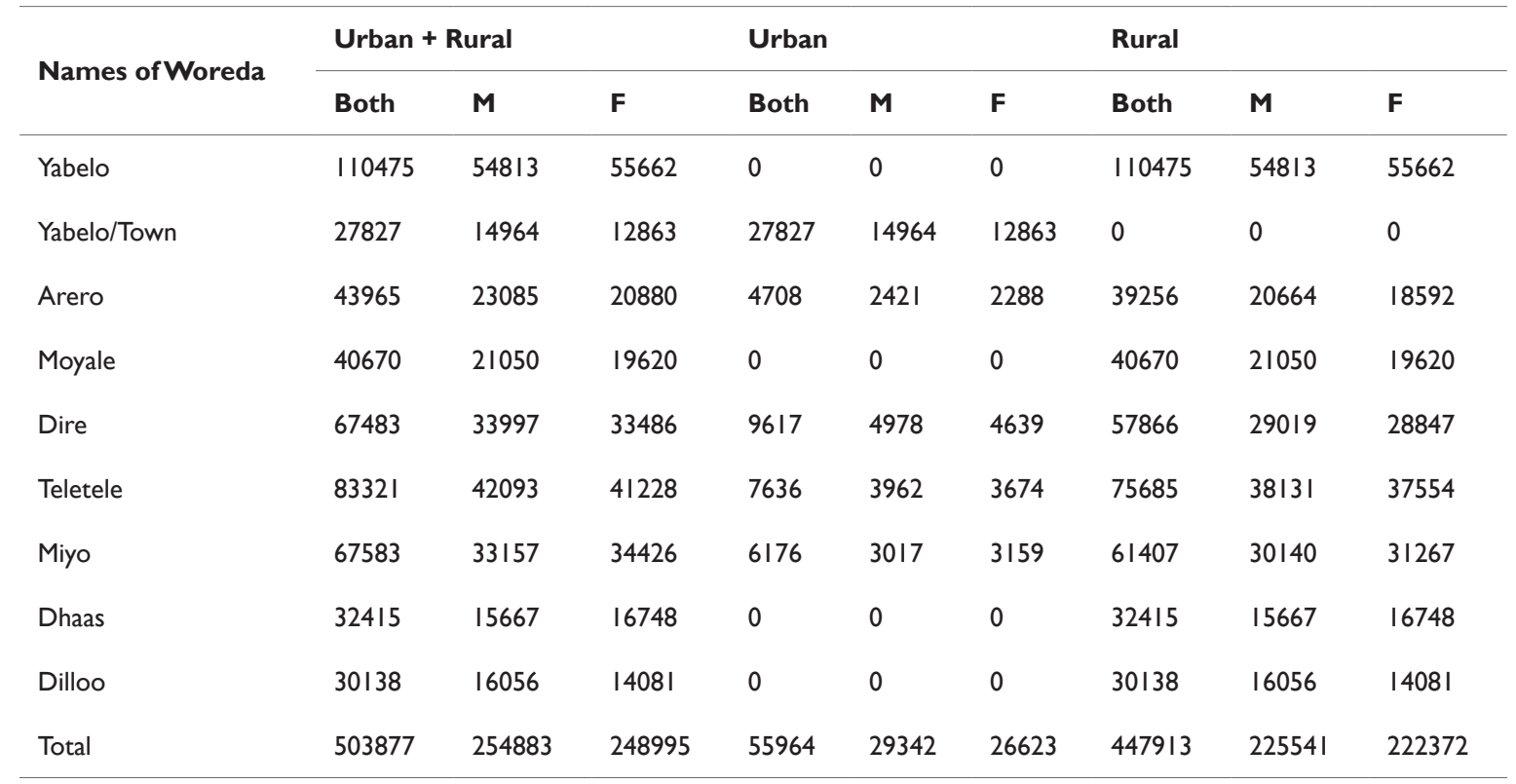

Source: Central Statistics Agency 2019 Projection

Table 3 Number of farmers association and urban kebeles in Borana zone

\begin{tabular}{|c|c|c|c|c|c|}
\hline \multirow[b]{2}{*}{ No } & \multirow[b]{2}{*}{ Name of district } & \multicolumn{4}{|c|}{ Total numbers of farmer association } \\
\hline & & Rural & Urban & Total & $\begin{array}{l}\text { Numbers of } \\
\text { DA in the zone }\end{array}$ \\
\hline I & Arero & 21 & I & 22 & 68 \\
\hline 2 & Dhas & 12 & I & 13 & 34 \\
\hline 3 & Dillo & 10 & I & II & 44 \\
\hline 4 & Dire & 16 & 2 & 18 & 57 \\
\hline 5 & Miyo & 16 & 2 & 18 & 60 \\
\hline 6 & Moyale & 18 & 2 & 20 & 59 \\
\hline 7 & Taltale & 22 & 2 & 24 & 48 \\
\hline 8 & Yabello Rural & 23 & 3 & 26 & 58 \\
\hline 9 & Yabello Urban & 0 & 0 & 0 & 0 \\
\hline \multicolumn{2}{|c|}{ Total in the zone } & 138 & 14 & 152 & 428 \\
\hline
\end{tabular}

Source: woreda statistical abstract

Table 4 Relief distribution in Borana zone

\begin{tabular}{llllll}
\hline \multicolumn{2}{l}{ Relief distributed trends } & & & \\
\hline Round & Month & Beneficiaries & \multicolumn{3}{l}{ Released } \\
\hline I-5th $\quad$ Jul-Dec. (every round) & 203,684 & Cereal & Oil & Pulses \\
\cline { 3 - 5 } & & $58,288.60$ & $1,511.91$ & 6747.93 \\
\hline
\end{tabular}

Source: Zone disaster prevention and preparedness office 
Table 5 Production of crops

\begin{tabular}{|c|c|c|c|}
\hline \multirow{2}{*}{ Season } & \multirow{2}{*}{ Unit } & \multicolumn{2}{|c|}{ Production year } \\
\hline & & 2018 & 2019 \\
\hline \multicolumn{4}{|l|}{ Belg season } \\
\hline Area & $\mathrm{Ha}$. & $193,118.20$ & $152,775.83$ \\
\hline Production & Quint. & $2, \mid 79,521$ & $812,365.92$ \\
\hline Productivity & Quint. & 11.28 & 5.31 \\
\hline cereal crop & $\mathrm{Ha}$. & 88,484 & $73,195.25$ \\
\hline Production & Quint. & 986073 & $389,689.44$ \\
\hline Productivity & Quint. & 11.14 & 5.32 \\
\hline Maize, sorghum... & Ha. & $66,777.40$ & $52,590.59$ \\
\hline Production & Quint. & $781,695.20$ & $279,977.48$ \\
\hline Productivity & Quint. & $11.7 \mid$ & 5.32 \\
\hline Cereal food & $\mathrm{Ha}$. & $37,856.80$ & $26,989.99$ \\
\hline Production & Quint. & $411,752.80$ & $142,700.89$ \\
\hline Productivity & Quint. & 10.88 & 5.29 \\
\hline \multicolumn{4}{|l|}{ Summer season } \\
\hline Area & Ha. & $82,098.50$ & 7646I.7I \\
\hline Production & Quint. & $473,036.30$ & 558442.95 \\
\hline Productivity & Quint. & 5.76 & 7.3 \\
\hline Wheat, barley... & Hect. & $9,145.50$ & $7,470.98$ \\
\hline Production & Quint. & $30,387.30$ & $36,290.77$ \\
\hline Productivity & Quint. & 3.32 & 4.86 \\
\hline Maize, sorghum... & $\mathrm{Ha}$. & 11,568 & 10,883 \\
\hline Production & Quint. & 97,331 & $92,046.98$ \\
\hline Productivity & Quint. & 8.41 & 8.46 \\
\hline Cereal food & $\mathrm{Ha}$. & 61,685 & $58,107.73$ \\
\hline Production & Quint. & 345318 & 430105.2 \\
\hline Productivity & Quint. & 5.59 & 7.4 \\
\hline
\end{tabular}

Source: Borana zone agriculture office. (Note: Quint, quantity; Ha, hectare)

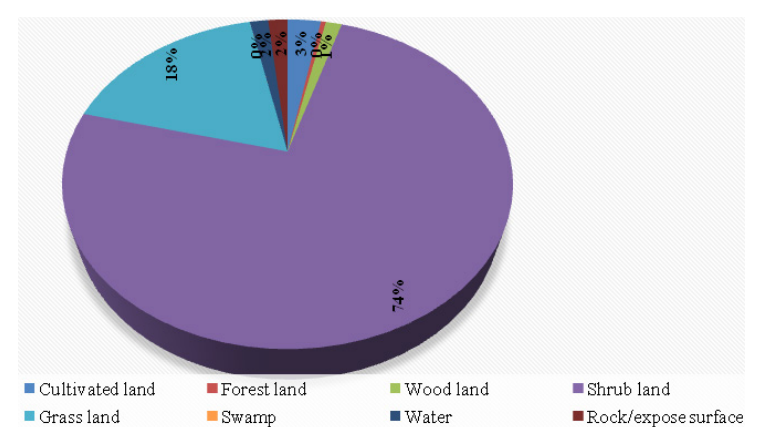

Figure 4 land use land cover change in Borana rangeland area (source: from Borana zone agricultural office 2019 data).

Livestock population: Borana zone is one of the pastoralist zones depending on livestock rearing, among livestock cattle 1,482,053 Goats 1,179,645 Sheep 637,632 Horses 2,222 Mules 5525 Donkeys 68,799 and Camels 185,382 the data for poultry is not available (Table $6)$.
The major livestock disease in Borana zone: The common and major livestock disease frequently occurred in Borana rangeland is listed below in Table 7.

Livestock veterinary infrastructure (Table 8) (Table 9) 
Table 6 Estimated livestock population number of Borana zone by district in 2018/2019

\begin{tabular}{lllllllll}
\hline No. & Name of district & Cattle & Goats & Sheep & Horses & Mules & Donkeys & Camels \\
\hline 1 & Arero & 134,370 & 68,023 & 37,321 & 23 & 1053 & 4594 & 32272 \\
2 & Dhas & 177,393 & 84,189 & 31,863 & 1221 & 1871 & 13,617 & 22155 \\
3 & Dillo & 104,621 & 114,280 & 119,595 & DNA & 728 & 8040 & 8173 \\
4 & Dirre & 113,020 & 83,419 & 65,021 & 413 & 268 & 4656 & 4683 \\
5 & Dubluq & 83,332 & 74,784 & 45,085 & 20 & 325 & 3722 & 4155 \\
6 & Elwoye & 115,200 & 100,039 & 43,591 & 98 & 185 & 3402 & 19,505 \\
7 & Gomole & 129,510 & 89,761 & 59,754 & 256 & 73 & 2643 & 28,484 \\
8 & Guchi & 62,000 & 48,000 & 26,000 & 10 & 16 & 1500 & 13,000 \\
9 & Miyo & 104,161 & 129,008 & 34,312 & 29 & 447 & 5108 & 7839 \\
10 & Moyale & 55,134 & 65,485 & 14,723 & 10 & DNA & 3500 & 16,918 \\
11 & Taltale & 197,876 & 185,846 & 105,158 & DNA & 65 & 9704 & 1062 \\
12 & Wachile & 101,436 & 50,772 & 17,618 & 4 & 335 & 5411 & 13,836 \\
13 & Yabelo & 104,000 & 86,039 & 37,591 & 138 & 159 & 2902 & 13,305 \\
14 & Yabello Town & - & - & - & - & - & - & - \\
Total & & $1,482,053$ & $1,179,645$ & 637,632 & 2,222 & 5525 & 68,799 & 185,382 \\
\hline
\end{tabular}

Source: Borana zone pastoralist office. Note: DNA, data note available

Table 7 Livestock disease in Borana zone

\begin{tabular}{lll}
\hline No & Types of live stocks disease in the zone & Type of live stocks mostly affected \\
\hline I & Anthrax & Cattle \\
2 & Trypanosome & All species affected \\
3 & Black leg & Cattle, Sheep and Goat \\
4 & bovine pastoralists & Cattle and Goat \\
5 & CBPP & Cattle \\
6 & CCPP & Goat \\
7 & FMD & Cattle \\
8 & LSD(lumpy skin disease) & Cattle and Goat \\
9 & Camel trpy & Camel \\
I0 & Sheep and goat pox & Sheep \& goat \\
II & Internal parasites & Cattle, sheep, camel, equin, poultry \\
I2 & External parasites & Cattle, sheep, camel, equin, poultry
\end{tabular}

Source: zone pastoralist development office

Table $\mathbf{8}$ Veterinary infrastructure in the zone

\begin{tabular}{lllllllllll}
\hline \multirow{2}{*}{ No. } & Type of & \multicolumn{2}{l}{ Districts } & & & & & & \\
\cline { 2 - 9 } & clinics & Arero & Dhas & Dilo & Dire & Miyo & Taltale & Moyale & Yabello & Total \\
\hline 3 & Type C & $\mathrm{I}$ & $\mathrm{I}$ & $\mathrm{I}$ & $\mathrm{I}$ & $\mathrm{I}$ & 2 & 2 & 1 & 10 \\
4 & Type D/Hp & 17 & 4 & 6 & 8 & 16 & 9 & 8 & 9 & 77 \\
Total & & 18 & 5 & 7 & 9 & 17 & 11 & 10 & 10 & 87 \\
\hline
\end{tabular}

Source: woreda socio-economic survey 
Table 9 Veterinary man power

\begin{tabular}{lllll}
\hline No. & Name of district & Doctors & Health assistant & Technician \\
\hline 1 & Arero & 3 & 24 & 2 \\
2 & Dhas & - & 23 & 1 \\
3 & Dillo & - & 22 & 4 \\
4 & Dire & 1 & 21 & - \\
5 & Miyo & 2 & 21 & 1 \\
6 & Moyale & 2 & 19 & 3 \\
7 & Taltale & 1 & 28 & 1 \\
8 & Yabello Rural & 1 & 16 & 7 \\
9 & Yabello Urban & - & - & - \\
& Total & 10 & 174 & 19 \\
\hline
\end{tabular}

Water source for livestock and pastoralist communities: Tape water (Bore hole fitted with hand pump), wells, pond and spring are the major sources of drinking water for both human and livestock in rural areas of Borana Zone. Similarly tape water (bore hole fitted with hand pump, motorized pump and solar pump are the major sources of drinking water for both livestock and human in the urban areas of the Borana zone. About $43 \%$ of total rural population of Borana zone supplied with potable water and $50 \%$ total urban of populations of Borana zone supplied with potable water (Table 10).

Construction of wells in Borana rangeland: Number of deep wells, shallow wells, hand-dug wells, spring development and distribution schemes giving services in the zone 2019 are given below Table 11.

Table 10 Rural population and urban population supplied with potable water in 2019

\begin{tabular}{lllllll}
\hline \multirow{2}{*}{ Woreda } & \multicolumn{7}{l}{ Number of populations supplied with portable water } & \multicolumn{2}{l}{ Coverage in \% } \\
\cline { 2 - 7 } & Rural & Urban & Total & Rural & Urban & Total \\
\hline Arero & $21,006.00$ & 418 & 21,424 & 53.510291 & 9.9880526 & 49.3174651 \\
Dhaas & $15,531.00$ & 2,165 & 17,696 & 47.913003 & 43.3 & 47.2965388 \\
Dilloo & $2,768.00$ & 3,844 & 6,612 & 9.1844183 & 89.187935 & 19.1941477 \\
Dire & $13,906.00$ & 8,548 & 22,454 & 24.031383 & 100 & 33.8091366 \\
Miyo & $26,218.00$ & 1,922 & 28,140 & 42.695458 & 34.996358 & 42.063409 \\
Moyale & $41,475.00$ & 11,209 & 52,684 & 101.97935 & 44.999799 & 80.3366931 \\
Teletele & $39,686.00$ & 2,567 & 42,253 & 52.435754 & 37.794464 & 51.2300399 \\
Yabelo & $30,406.00$ & 9,954 & 40,360 & 27.522969 & 97.245018 & 33.4352296 \\
Yabelo town & - & 6,217 & 6217 & & 25.50041 & 25.5004102 \\
Total & $190,996.00$ & 46844 & 237,840 & 43 & 50 & 43.901034 \\
\hline
\end{tabular}

Source: Borana zone water and mineral office

Table II Wells and its type that found in Borana zone

\begin{tabular}{lllll}
\hline Zone & Deep wells & Shallow wells & Hand-dug wells & Spring development \\
\hline Borana & 72 & 214 & 36 & 65 \\
\hline
\end{tabular}

Source: Borana zone water and mineral office

\section{Livestock trade and market activities}

Borana zone is known for its livestock production. The main livestock products such as animals' hides and skins are exported to the national market and even to Kenya through illegal way Trade is defined as the flow of goods and services across international land borders within a reach of duly defined area. It has two varietiesformal and informal. The former refers to trade in goods or services which is carried out by legally registered traders and fulfills all legal requirements of the trading countries while the later refers to movement of goods in which all or part of the trading activity is unrecorded or unrecognized by the government, and without adherence to procedural requirements of all formal institutions. The formal trade is classified in to two: large scale formal trade and small-scale formal trade. Our Zone has a legal framework for the formal small-scale trade which is often referred to as petty periphery trade (Table 12). 
Table 12 Legal and Illegal trade trend for the last four years in Borana zone at 2019

\begin{tabular}{lllll}
\hline No & Years & Unit & Legal trade & Illegal trade \\
\hline I & 2016 & No. & 7,046 & 3,001 \\
2 & 2017 & No. & 8,359 & 2,782 \\
3 & 2018 & No. & 9,557 & 2,669 \\
4 & 2019 (up to May) & No. & 6,706 & 1,045 \\
\hline
\end{tabular}

Source: Borana Zone Annual Report of, 2019

The livestock marketing system was founded upon a complex trading chain involving producers, intermediaries, traders and numerous other market participants. Animals move from bush, primary and secondary markets along key trading routes and corridors to terminal and export markets. This trading network spans ,beyond major secondary livestock market hubs such as Moyale Woreda (moyale), Dubuluq Woreda (dubuluq), Yabalo Woreda, (Haro-Bake), Taltale (Milemi), Arero Woreda (mataGefersa), Elowaye woreda

Table 13 Functional market place in Borana zone (elowaye), DhasWoeda borbor), Dilo Woreda (dilo) the cross-border livestock trade is an integral part of life among communities living in remote pastoral areas. While proximity to the border can provide important benefits to adjacent communities, particularly in terms of drought coping mechanisms, communities can enjoy these benefits only during periods of peace. The major functional market place in Borana zone were listed blew in Table 13 (Figure 5) (Table 14).

\begin{tabular}{|c|c|c|c|c|c|}
\hline \multirow{2}{*}{ No } & \multirow{2}{*}{ Name of market district } & \multicolumn{3}{|c|}{ No of market place In Borana Zone } & \multirow{2}{*}{ Tota } \\
\hline & & Bush Market & Primary market & 2dry market & \\
\hline I & Yabelo Town & 0 & Yabelo & 0 & I \\
\hline 2 & Yabelo woreda & Didara & 0 & Haro bake & 2 \\
\hline 3 & Arero woreda & Alona & 0 & Mata gefersa & 2 \\
\hline 4 & Dire woreda & Mana soda & Mega, magado & 0 & 3 \\
\hline 5 & Dubuluq Woreda & 0 & 0 & Dubuluq & I \\
\hline 6 & Miyo Woreda & 0 & Hidi & 0 & I \\
\hline 7 & Dilo woreda & 0 & 0 & Dilo & I \\
\hline 8 & Taltale woreda & Dibegaya & 0 & Milemi & 2 \\
\hline 9 & Elowaye woreda & 0 & 0 & Elowaye & I \\
\hline 10 & Gomole Woreda & 0 & surupa & 0 & 1 \\
\hline 11 & Das woreda & 0 & 0 & Borbor & 1 \\
\hline 12 & Moyale woreda & Tuka & 0 & Moyale & 2 \\
\hline 13 & Guci & 0 & 0 & 0 & 0 \\
\hline \multirow[t]{2}{*}{14} & Wacile & 0 & 0 & 0 & 0 \\
\hline & Total market & 5 & 5 & 8 & 18 \\
\hline
\end{tabular}

Source: Borana Zone Annual Report of, 2019

Table I4 Trend of livestock supply to market from 2016- May, 2019

\begin{tabular}{|c|c|c|c|c|c|}
\hline No. & Livestock type & 2016 & 2017 & 2018 & 2019 (up to may) \\
\hline I & Cattle & 207,032 & 162,300 & 333,375 & $|82,5| 8$ \\
\hline 2 & Goat & 200,406 & 105,000 & 296,648 & 170,663 \\
\hline 3 & Sheep & 174,570 & 35,000 & 106,369 & 62,259 \\
\hline 4 & Camels & 92,540 & 17,000 & 38361 & 25,553 \\
\hline Total & & 676,652 & 321,315 & 776,769 & 440,993 \\
\hline
\end{tabular}

Source: Borana Zone Annual Report of (2016- 2019) 


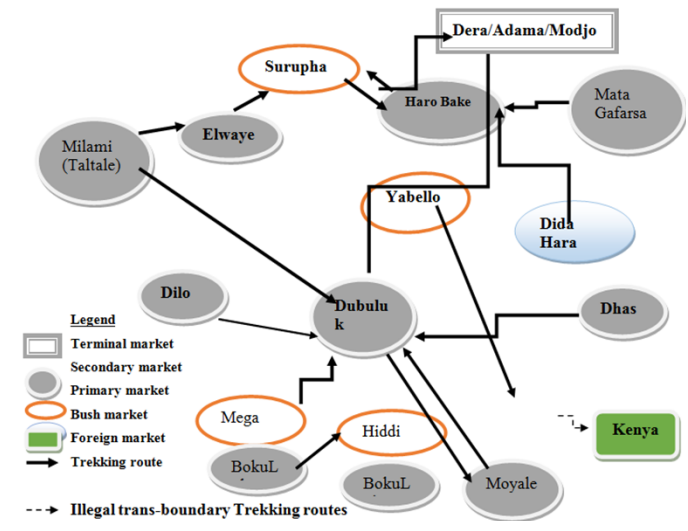

Figure 5 Livestock market stock route in Borana pastoral areas.

\section{Livestock marketing constraints}

Some of the major marketing exchange challenges found in Borana zone based on the data obtained from interview result and different written documents are the following:

a. Poor awareness of business and marketing concept and lack of marketing experience

b. Absence of organized Live Animals Traders Association

c. Presence of non-value adding brokers and their negative impact on the marketing processes.

d. Lack of effective and sustainable livestock market out-lets

e. Lack of access to well organized marketing system

f. Long chain of livestock marketing channel and unsustainable marketing chains.

g. Poor marketing infrastructure development

h. Poor marketing information system

i. The livestock marketing of the area is constrained by week husbandry and sanitary control system

j. There is a lack of market-oriented production system in the areas due to week livestock market extension services. ${ }^{8}$

\section{Conclusion}

In general, understanding of the overall socio- economic activities and practice of a certain area is very essential for future activities like research, community service and other. So, the main objective of this assessment is to identify the general background system for Borana rangeland and identifying the major problems and used to plan how to solve it substantially. And I highly recommend that while we need to do any research or activity, understand the general background information of the planned study site is very essential and important to get the exact and community basic need and this help us to achieve our plan without more time and budget too.

\section{Acknowledgments}

None.

\section{Funding}

None.

\section{Conflicts of interest}

The authors declare there are no conflicts of interest.

\section{References}

1. Dalle G, Maass BL, Isselstein J. Rangeland condition and trend in the semi-arid Borana lowlands, southern Oromia, Ethiopia. African Journal of Range \& Forage Science. 2015;23(1):49-58.

2. Gemedo D, Maass BL, Isselstein J. Plant communities and their species diversity in the semi-arid rangelands of Borana lowlands, southern Oromia, Ethiopia. Community Ecology. 2005;6(2):167-176.

3. Statistical abstracts of Borana zone, southern Ethiopia. 2019.

4. Samuels I, Cupido C, Swarts MB, et al. Feeding ecology of four livestock species under different management in a semi-arid pastoral system in South Africa. African Journal of Range and Forage Science. 2015:1-9.

5. Asmare B, Solomon D, Taye T, et al. Effects of altitude and harvesting dates on morphological characteristics, yield and nutritive value of desho grass (PennisetumpedicellatumTrin.) in Ethiopia. Agric Nat Resour. 2017;51:148-153.

6. Coppock DL. The Borana plateau of southern Ethiopia: Synthesis of pastoral research, development and change. Addis Ababa, Ethiopia: Livestock Center for Africa; 1994.

7. Ethiopian Meteorological Agency. Recorded rainfall and temperature data of borana regionrangeland; Ethiopian meteorological agency: Addis Ababa, Ethiopia; 2019.

8. Borana zone agricultural office data. Land use land cover change in Borana rangeland area. 2019. 